\title{
Emulsifiers Produced by Locally Microbes Using Local Agro-Industrial Wastes
}

\author{
Abdullah M El Mahdii ${ }^{1}$, Hamidi Abdul Azizi, ${ }^{1,2}$, Nour Sh. El-Gendy ${ }^{3}$ \\ ${ }^{1}$ Department of Technical Affairs, Arabian Gulf Oil Co (AGOCO) Benghazi, Libya \\ ${ }^{2}$ School of Civil Engineering, Engineering Campus, Universiti Sains Malaysia, 14300 NibongTebal, Penang, Malaysia \\ ${ }^{3}$ Solid Waste Management Cluster, Engineering Campus, Universiti Sains Malaysia, 14300 Penang, Malaysia \\ ${ }^{3}$ Egyptian Petroleum Research Institute, Nasr City, Cairo 11727, Egypt
}

Submission: June 14, 2017; Published: June 30, 2017

*Corresponding author: School of Civil Engineering, Engineering Campus, Solid Waste Management Cluster,Universiti Sains Malaysia,14300 Nibong Tebal, Penang, Malaysia, Email: cehamidi@usm.my

\begin{abstract}
Crude oil causes a variety of risks when released into the marine environment. Biodegradation of hydrocarbon compounds is one of the most important processes for cleanup of the environment. Identification of the key organisms that play roles in pollutant biodegradation is important for understanding bioremediation strategies. Therefore, this study aims to investigate the effects of crude oil concentration on its biodegradation in seawater as well as optimization of media or nutrients concentration for improved hydrocarbon removal in two different densities of Libyan crude oil concentrations. This study highlights the use of low-cost agro-industrial raw material corn steep liquor (CSL) and solid waste dates (SWD) for fermentative production of bio surfactants because of its effectiveness, economic concerns, and environmental compatibility.
\end{abstract}

Keywords: Marine; Oil pollution; Biodegradation; Agro industrial wastes

\section{Introduction}

Mediterranean Sea is a semi enclosed basins having one of the maximum pollution related incidences due to high oil producing and refining centers along its coast. Besides, it is the major transport hub for most of the oil transported. This high traffic density is one of the reasons for increased pollution of the Mediterranean Sea. Moreover, the high incidence of oil spills has made it most polluted regions of the world. Therefore, the countries along the Mediterranean Sea have framed stringent marine regulations for overcoming pollution activities and have encouraged bioremediation studies in seriously affected areas of the region Daffonchio et al. [1]. Libya is particularly affected due to its location, the Mediterranean country with maximum oil reserves $[2,3]$.

The potential hot spots in the Mediterranean belt are lined with numerous pipeline terminals, oil refineries, and offshore platforms. The countries particularly on the southern side are major oil and gas producers. Naturally, they are major hot spots for pollution and have serious ecology disruption in their vicinity. Whereas, the northern region of the basin are main oil importers and have many oil refinery terminals that receive the oil and gas from this southern oil belt. The two regions are well connected by oil and gas pipelines and many additional pipelines are being developed. Besides, offshore oil drilling and extracting works are being increasingly carried out with the discovery of new oil and gas wells. All these have contributed to the pollution of the Mediterranean Sea and therefore are of major concern $[4,5]$.

Many of these polluted sites are located within delicate ecosystems, like those of coastal lakes and lagoons that would strongly benefit from the decrease of pollution levels. The conventional methods currently in use are costly and leave toxic residues in the environment. In contrast, bioremediation including enhanced natural attenuation is a promising technology in the treatment of petroleum hydrocarbon contamination because of its high effectiveness, lower cost and environmental friendly Chandra et al. [6]. Most of these sites demand an urgent application of sustainable clean-up strategies based on biological approaches to recover the general 
environmental quality and the safety for the Mediterranean residents living in the nearby regions. Essentially oil countries, such as Libya, have easy access to agro-industrial by products. When solid waste date (SWD) was used as the sole carbon and energy source for bio surfactant producing bacteria, the biodegradation process well enhanced. Indigenous organisms isolated in this study were selected by enrichment culturing technique. These isolates consisted of strains P. aeruginosa NAF1 and K. palustrisSAR3. The Pseudomonas strains was seen to be able to tolerate and grow in high concentrations (up to $10 \%$ ) of crude oil and were able to utilize compounds such as aliphatic and mono aromatic hydrocarbons as substrates and known as one of the most useful tools in bioremediation of petroleum polluted sites. In the first part of study, the effects of initial crude oil concentration, CSL, and SWD on the rate of bioremediation of petroleum hydrocarbons in seawater samples were investigated for concentration of $5000 \mathrm{mg} / \mathrm{L}$. In crude oil (CO) experiments, bioreactors were supplemented with the crude oil at a ratio of $0.5 \%$ and $0.2 \%(w / v)$ CSL or SWD. In natural attenuation (no nutrient addition), $22 \%$ of crude oil were removed in 28 days. The maximum removal of C035 was $91.15 \%$ using 5g/L CSL and 6.3g/L C035.

\section{Discussion and Result}

The success of bioremediation depends on having the appropriate microorganisms in place under suitable environmental conditions and composition of the contaminant. Although biodegradation was shown to be successful in naturally remediating oil contamination associated with several spills that impacted marine shorelines [7]. Much remains to be learned about the environmental controls of hydrocarbon degradation in marine environment. Replacing traditional microbiological media with agro industrial wastes as substrates for bio surfactant production holds great potential $[8,9]$. reported that the bacterium Pseudomonas cepacia CCT6659 cultivated with $2 \%$ soybean waste frying oil and $2 \%$ corn steep liquor as substrates produced a bio surfactant with potential application in the bioremediation of hydrocarbons. Significant oil biodegradation activity (83\%) occurred in the first 10 days. It is evident from the results that the bio surfactant alone and its producer species are both capable of promoting biodegradation to a large extent. This result is in accordance with the findings of Silva et al. [9]. All these approaches can make the bioremediation process an economically and environmentally viable mitigation technology.

The maximum removal of CO39 was $99.10 \%$ using $5 \mathrm{~g} / \mathrm{L} \mathrm{CSL}$ and $6.3 \mathrm{~g} / \mathrm{L}$ C039 in an incubation time of $28 \mathrm{~d}$. Also compared the removal rates of $\mathrm{CO} 35(10.4 \%)$ and C039 (10.3\%) without the addition of CSL. The optimum conditions obtained were 2g/L CSL at 15 and $10 \mathrm{~d}$, and 10g CO35 (81.16\%) and C039 (88.12\%). The predicted results of $76.12 \%$ and $84.04 \%$ fitted well with the results of laboratory experiments. The optimum conditions obtained were SWD of 2.1 and $2 \mathrm{~g} / \mathrm{L}$ in 11 and 14 days with $\mathrm{CO} 35$ and C039 biodegradations of $79.49 \%$ and $94.15 \%$, respectively. The predicted results of $82.10 \%$ and 95.45\% fitted well with experimental results (CO35 and CO39 removal rates of $97.15 \%$ and $99.10 \%$, respectively). Based on removal rates of $8.53 \%$ and $12.13 \%$ for both CO35 and C039 without SWD, respectively, in 28 days, the obtained results shown in (Table 1) revealed that CSL and SWD were very efficient in improving the biodegradation of Libyan crude oils that contaminate seawater.

Table 1: Summary results for $\mathrm{CO} 35$ and $\mathrm{CO} 39$ biodegradation with Solid waste dates.

\begin{tabular}{|c|c|c|c|c|c|c|}
\hline \multicolumn{3}{|c|}{ Factors } & \multicolumn{2}{c|}{ C035 removal \% } & \multicolumn{2}{c|}{ C039 removal \% } \\
\hline Crude oil Conc.(w/v) & SWD Conc.(w/v) & Time & & & \\
\hline (day) & Observed & Predicted & Observed & Predicted & & \\
\hline 0.63 & 0.50 & 28.00 & 97.15 & 95.76 & 99.10 & 92.96 \\
\hline 0.25 & 0.20 & 07.00 & 75.80 & 76.61 & 88.65 & 88.30 \\
\hline 1.00 & 0.21 & 11.00 & 79.00 & 82.00 & - & - \\
\hline 1.00 & 0.20 & 14.00 & - & - & 94.00 & 95.00 \\
\hline
\end{tabular}

\section{Conclusion}

The biotechnology process used in this study was simple, inexpensive, efficient and environmentally compatible because we used local waste raw material to increase crude oil removal with experimental condition harmonizes industry with environment. This study revealed that the exclusive use of agricultural wastes for microbial growth and production of effective surface active substances is feasible and has promising applications in order to enhance the bioavailability and biological treatment of environmental pollutants. Bioremediation processes are intriguing and many opportunities exist to further elucidate the application of our locally bacterial isolates on industrial scale.

\section{Acknowledgment}

The authors acknowledge the staff and team of technicians at AGOCO for their encouragement and support. The Arabian Gulf Oil Co. of Libya funded this work. 


\section{References}

1. Daffonchio D, Ferrer M, Mapelli F, Cherif A, Lafraya Á, et al. (2013) Bioremediation of Southern Mediterranean oil polluted sites comes of age. New biotechnology 30(6): 743-748.

2. Daffonchio D, Mapelli F, Cherif A, Malkawi HI, Yakimov MM, et al. (2012) ULIXES, unravelling and exploiting Mediterranean Sea microbial diversity and ecology for xenobiotics' and pollutants' clean up. Reviews in Environmental Science and Bio/Technology 11(3): 207-211.

3. Toklu E, Yeğin M, Kaygusuz K (2013) Sustainable energy policies in Mediterranean region: a case of Turkey. Journal of Engineering Research and Applied Science 2(1): 122-137.

4. Margottini L (2011) Gulf drilling disaster triggers scrutiny of mediterranean oil rush. Science 333(6040): 285.

5. Mandalakis M, Polymenakou PN, Tselepides A, Lampadariou N (2014) Distribution of aliphatic hydrocarbons, polycyclic aromatic hydrocarbons and organo chlorinated pollutants in deep-sea sediments of the southern Cretan margin, eastern Mediterranean Sea: A baseline assessment. Chemosphere 106: 28-35.

6. Chandra S, Sharma R, Singh K, Sharma A (2013) Application of bioremediation technology in the environment contaminated with petroleum hydrocarbon. Annals of Microbiology 63(2): 417-431.

7. Atlas RM, Hazen TC (2011) Oil biodegradation and bioremediation: a tale of the two worst spills in US history. Environmental science \& technology 45(16): 6709-6715.

8. Khan MSA, Singh B, Cameotra SS (2014) Biological Applications of Bio surfactants and Strategies to Potentiate Commercial Production. Biosurfactans: Production and Utilization Processes, Technologies, and Economics 159: 269.

9. Silva EJ, Rochae Silva NMP, Rufino RD, Luna JM, Silva RO, et al. (2014) Characterization of a bio surfactant produced by Pseudomonas cepacia CCT6659 in the presence of industrial wastes and its application in the biodegradation of hydrophobic compounds in soil. Colloids Surf B Biointerfaces 117: 36-41.

\section{Your next submission with Juniper Publishers will reach you the below assets}

- Quality Editorial service

- Swift Peer Review

- Reprints availability

- E-prints Service

- Manuscript Podcast for convenient understanding

- Global attainment for your research

- Manuscript accessibility in different formats

( Pdf, E-pub, Full Text, Audio)

- Unceasing customer service

Track the below URL for one-step submission https://juniperpublishers.com/online-submission.php 